\title{
Symbiotic nitrogen fixation in legume nodules: process and signaling. A review
}

\author{
Neera GARG*, GEETANJALI \\ Department of Botany, Panjab University, Chandigarh - 160014, India
}

(Accepted 9 November 2006)

\begin{abstract}
The Green Revolution was accompanied by a huge increase in the application of fertilizers, particularly nitrogen. Recent studies indicate that a sizeable proportion of the human population depends on synthetic nitrogen $(\mathrm{N})$ fertilizers to provide the 53 million $\mathrm{t} \mathrm{N}$ that is harvested globally in food crops each year. Nitrogen fertilizers affect the balance of the global nitrogen cycle, pollute groundwater and increase atmospheric nitrous oxide $\left(\mathrm{N}_{2} \mathrm{O}\right)$, a potent "greenhouse" gas. The production of nitrogen fertilizer by industrial nitrogen fixation not only depletes our finite reserves of fossil fuels, but also generates large quantities of carbon dioxide, contributing to global warming. The process of biological nitrogen fixation offers an economically attractive and ecologically sound means of reducing external nitrogen input and improving the quality and quantity of internal resources. Recent studies show that in irrigated cropping systems, legume $\mathrm{N}$ is generally less susceptible to loss processes than fertilizers. Biological nitrogen fixation (BNF) has provided a number of useful paradigms for both basic and applied research. Establishing a fully functional symbiosis requires a successful completion of numerous steps that lead from recognition signals exchanged between the plant and bacteria to the differentiation and operation of root nodules, the plant organ in which nitrogen fixation takes place. The initial sensing of the two organisms by each other starts with the release of root exudates by the plant that include flavonoids and nutrients such as organic acids and amino acids. Flavonoids secreted by the host plant into the rhizosphere function as inducers of the rhizobial nod genes. nod gene induction results in the secretion of lipochitin oligosaccharides that are thought to bind to specific plant receptor kinases that contain LysM motifs, such as NFR1 and NFR5 in Lotus japonicus and LYK3 and LTK4 in Medicago truncatula. This initiates a complex signaling pathway involving calcium spiking in root hairs. The result is that the root hairs curl and trap the rhizobia, which then enter the root hair through tubular structures known as infection threads that are formed by the plant. The infection threads then grow into the developed nodule tissue. Ultimately, the invading bacteria are taken into the plant cell by a type of endocytosis in which they are surrounded by a plant-derived peribacteroid membrane (PBM). The resulting symbiosomes fill the plant cell cytoplasm and as plant and bacterial metabolism develops, the bacteria become mature bacteroids able to convert atmospheric nitrogen to ammonium. To increase knowledge of this system of particular importance in sustainable agriculture, major emphasis should be laid on the basic research. More work is needed on the genes responsible in rhizobia and legumes, the structural chemical bases of rhizobia/legume communication, and signal transduction pathways responsible for the finely orchestrated induction of the symbiosis-specific genes involved in nodule development and nitrogen fixation. This review unfolds the various events involved in the progression of symbiosis.
\end{abstract}

flavonoids / nitrogen fixation / nod factors / Rhizobium / sustainable agriculture

\section{INTRODUCTION}

A key component to the success of the "green revolution" in improving the yields of crops like rice and wheat was the increased input of synthetic fertilizers. Nitrogen fertilizers today are an indispensable part of modern agricultural practices and rank first among the external inputs to maximize output in agriculture. However, $\mathrm{N}$ fertilizer contributes substantially to environmental pollution. The continued and unabated use of $\mathrm{N}$ fertilizers would accelerate the depletion of stocks of non-renewable energy resources used in fertilizer production. The removal of large quantities of crop produce from the land depletes soil of its native $\mathrm{N}$ reserves (Peoples and Craswell, 1992). There are vast areas of the developing world where $\mathrm{N}$ fertilizers are neither available nor affordable due to weak infrastructure, poor transportation, and high cost. Even in wealthier nations, economic and environmental considerations dictate that biological alternatives, which can augment and in some cases replace, $\mathrm{N}$ fertilizers must be sought (Bohlool et al., 1992). Thus, emphasis should be laid in developing new production methods that are sustainable both agronomically and economically. Biological nitrogen fixation (BNF) can act as a renewable and environmentally sustainable source of $\mathrm{N}$ and can complement or replace fertilizer inputs (Peoples et al., 1995). Its use can mitigate the need for fertilizer nitrogen, with concomitant benefits accruing in terms of effects on the global nitrogen cycle, global warming, and groundand surface-water contamination. Intercropping legumes and other species capable of symbiotic $\mathrm{N}_{2}$ fixation offer an economically attractive and ecologically sound means of reducing external inputs and improving the quality and quantity of internal resources. Nitrogen from this source (biologically fixed $\mathrm{N}_{2}$ ) is used directly by the plant, and so is less susceptible to volatilization, denitrification and leaching. BNF is a kind of beneficial plant-microbe interaction that provides a restricted

\footnotetext{
*Corresponding author: gargneera@yahoo.co.in
} 
range of plants with the often-limiting macronutrient-nitrogen. This type of symbiosis evolved some 60 million years ago and is an archetypal example of a monospecific association (Bonfante, 2003; Hirsch, 2004).

Biological nitrogen fixation is done by both free-living organisms (e.g. Azotobacter, Beijerinckia, Clostridium, Bacillus, Klebsiella, Chromatium, Rhodospirillum) and those that form symbiotic associations with other organisms. In agricultural settings, perhaps $80 \%$ of this biologically fixed $\mathrm{N}_{2}$ comes from symbiosis involving leguminous plants and $\alpha$-proteobacteria, order Rhizobiales, family Rhizobiaceae, including species of Rhizobium, Bradyrhizobium, Sinorhizobium, Azorhizobium and Mesorhizobium (Willems and Collins, 1993; Farrand et al., 2003). Recently, it has been shown that $\beta$-proteobacteria may also participate in this kind of relationship (Sawada et al., 2003). The legumes are a diverse and important family of angiosperms. With more than 650 genera and 18000 species, legumes are the third largest family of higher plants and are second only to grasses in agricultural importance (Doyle, 2001). Legumes provide largest single source of vegetable protein in human diets and livestock feed. Legumes are divided into three subfamilies, Mimosoideae, Caesalpinoideae, and Papilionoideae. Most cultivated legumes are found within the Papilionoideae, the subfamily with largest total number of genera. Of the three subfamilies of legumes, over $90 \%$ of the Papilionoideae and Mimosoideae, nodulate, whereas less than $30 \%$ nodulate in the more ancient Caesalpinioideae (Doyle, 2001). Worldwide, legumes are grown on approximately 250 Mha and they fix about $90 \mathrm{Tg}$ of $\mathrm{N}_{2}$ per year (Kinzig and Socolow, 1994). Legume productivity is theoretically independent of soil nitrogen status and they provide important grain and forage crops in both temperate and tropical zones (Cooper, 2004).

\section{INVADING THE PLANT}

\subsection{Detection of and response to host-released signals by members of rhizobiaceae}

Bacterial chemotaxis towards plant root exudates is a crucial event in legume-Rhizobium interactions. Plants exude high levels of nutrients, and many of these act as chemoattractants for the bacteria. Different strains have been described to be positively chemotactic to sugars, amino acids, various dicarboxylic acids such as succinate, malate, fumarate, and aromatic compounds (Bergman et al., 1991; Robinson and Bauer, 1993).

Binding of rhizobia to plant surfaces is essential for establishing a long-term interaction of the bacteria with their hosts. Plant lectins (proteins that possess at least one non catalytic domain that binds reversibly to mono- or oligosaccharides) could serve as receptors for bacterial exopolysaccharides (EPS). Lectins might mediate specificity in the Rhizobium - legume symbiosis (Ridge et al., 1998; Heeb and Haas, 2001; Rudiger and Gabius, 2001). Binding of rhizobia to plant surfaces is thought to take place in two steps. The first is a rather weak and reversible binding step that may involve a variety of bacterial polysaccharides. The products of the $n d v A$ and $n d v B$ genes in Sinorhizobium meliloti are involved in the synthesis of a cyclic glucan (Stanfield et al., 1988; Ielpi et al., 1990), which could act as an adhesin via gelling interactions with host polysaccharides or could interact with plant lectins (Heeb and Haas, 2001). The second binding step requires the synthesis of bacterial cellulose, which causes a tight, irreversible binding and formation of bacterial aggregates on the host surface (Robertson et al., 1988).

\subsection{Host detection during nodule formation}

Nitrogen fixation can only occur when the plants are in the symbiotic state and the Rhizobia invade the root or stem cortex (Cooper, 2004). The progression to the symbiotic state by two initially independent, free-living partners is governed by reciprocal signal generation and perception, which has been described as "molecular dialogue" (De'narie et al., 1993). This leads to a gradual and coordinated differentiation and adjustment of physiology and metabolism in both partners (Schultze and Kondorosi, 1998; Bladergroen and Spaink, 1998; Broughton et al., 2000; Perret et al., 2000; Spaink, 2000).

\subsection{Early signals from legume to rhizobia}

Detection of the signals leads to altered patterns of gene expression that culminate in specific and adaptive changes in bacterial physiology that are required for these associations (Brencic and Winans, 2005). Symbiotic interaction is initiated by micromolar or nanomolar concentrations of flavonoids or isoflavonoids in legume root or seed exudates. These compounds may initially assist rhizosphere colonization by acting as chemoattractants or less likely, as growth enhancers for rhizobia (Schultze and Kondorosi, 1998; Copper, 2004).

\subsection{Structure and function of flavonoids}

Flavonoids are secondary metabolic products of the central phenylpropanoid pathway and the acetate-malonate pathway of plants. Thus, all falvonoids are derivatives of phenylalanine from the shikimic acid pathway and malonyl CoA from the acetyl CoA carboxylase reaction. They are polycyclic aromatic compounds, released by plants into the rhizosphere (Barbour et al., 1991; Kape et al., 1991). These are 2-phenyl-1,4-benzopyrone derivatives. Their structure is defined by two aromatic rings, $\mathrm{A}$ and $\mathrm{B}$, and a heterocyclic pyran or pyrone ring the $\mathrm{C}$ ring. Specific modifications of this basic structure produce different classes of flavonoids including chalcones, flavanones, flavones, flavonols, isoflavonoids, coumestans, and anthocyanidines (Harborne and Williams, 2000, 2001). So far more than 4000 different flavonoids have been identified in vascular plants (Perret et al., 2000). Not all of them, however, are active as inducers of the nodulation genes. Comparison of structure of different nod-inducing 
flavonoids revealed that hydroxylation at the C-7, and C-4 positions are important for nod-inducing activity (Cunningham et al., 1991). Host legumes are thought to be discriminated from non-hosts partly on the basis of the specific flavonoids that they release (Hirsch et al., 2001; Parniske and Downie, 2003).

Flavonoids acting as primary signals to rhizobia have been found in legume seed coat and root exudates (Hartwig and Phillips, 1991). Flavonoids are released in their greatest amounts near root tips (Hartwig et al., 1990; Graham, 1991), and optimal concentrations occur near the emerging root hair zone, which is most favourable site for rhizobium infection (Zuanazzi et al., 1998). Their main role in the initiation of a rhizobial symbiosis is an interaction with the constitutively expressed nodD gene product(s) of the microsymbiont to form a protein-phenolic complex - a transcriptional regulator of other rhizobial nodulation (nod) genes that are responsible for synthesis of reciprocal signals to the plant root. The combination of Nod D proteins with appropriate plant flavonoids triggers the production of highly specific reverse signal molecules by rhizobia - the chitolipooligosaccharide (CLOS) Nod factors by means of the transcriptional activation of common and host specific nod genes (Cooper, 2004).

In addition to the flavonoids, several nonflavonoid nod inducers have been identified. Stachydrin (N-methylproline methylbetaine) and trigonelline (nictotinic acid $\mathrm{N}$ methylbetaine) were identified from exudates of alfalfa seedlings as inducers of nod genes in S. meliloti (Phillips et al., 1992). These molecules are quaternary ammonium compounds collectively known as betaines (Chen and Murata, 2002). Both trigonelline and stachydrine have been found in seeds, roots, and root exudates of various legumes (Rozan et al., 2000, 2001). The concentrations (in low millimolar range) of betaines required for nod induction are much higher than those of flavonoids (low micromolar range (Phillips et al., 1994). Two aldonic acids (tetronic acid and erytronic acid), as well as some simple phenolics (vanillin, coniferyl alcohol, chlorogenic acid, and ferulic acid) were also identified as natural inducers of nod genes in certain rhizobial species (Kape et al., 1991; Gagnon and Ibrahim, 1998). The concentrations required for their activity are similar to those of betaines (Kape et al., 1991).

\subsection{Reverse signals from rhizobia to legume roots - the chitolipooligosaccharide nod factors}

The key event in nodule formation is the synthesis and release by the bacteria of small molecules that are detected by the plant and that trigger the formation of the nodule (Long, 1996; Downie, 1998; Hadri and Bisseling, 1998; Cullimore et al., 2001; Geurts and Bisseling, 2002). These molecules are called Nod factors. Detection of Nod factors by a legume host induces major developmental changes in the plant, which are required for entry of the rhizobia into the host (Downie and Walker, 1999; Geurts and Bisseling, 2002). The tip of a root hair, to which rhizobia are bound, curls back on itself, trapping the bacteria within a pocket, from which they are taken up into a plant made intracellular infection thread. Nod factors also induce cell division and gene expression in the root cortex and pericycle, where they initiate development of the nodule (Truchet et al., 1991; Horvath et al., 1993; Spaink, 1996; Cullimore et al., 2001).

\subsection{Structure and function of Nod factors}

The structure of Nod factors was first determined in 1990 for Sinorhizobium meliloti (Lerouge et al., 1990). Nod factors usually comprise four or five $\beta$-1-4-linked $\mathrm{N}$-acetyl glucosamine residues with a long acyl chain that is attached to the terminal glucosamine. Many Nod factors from different rhizobia species have been identified and shown to differ with regard to the number of glucosamine residues, the length and saturation of acylchain and the nature of modifications on this basic backbone (Denarie et al., 1996; Downie, 1998). These host specific modifications include the addition of sulphuryl, methyl, carbamoyl, acetyl, fucosyl, arabinosyl and other groups to different positions on the backbone, as well as differences in the structure of the acyl chain. These variations define much of the species specificity that is observed in the symbiosis (Perret et al., 2000). Proteins encoded by bacterial genes $\operatorname{nod} A, \operatorname{nod} B$, and $\operatorname{nod} C$ are involved in the biosynthesis of the basic LCO structure (John et al., 1993; Geremia et al., 1994; Rohrig et al., 1994; Brencic and Winans, 2005). Many different nod genes are involved in modifying the basic LCO structure specifically for different rhizobia. For instance, nodH encodes a sulfotransferase that transfers a sulfate group to the reducing end of Nod factors of $R$. meliloti (Roche et al., 1991; Bourdineaud et al., 1995; Ehrhardt et al., 1995).

\subsection{Transcriptional regulators of nod genes}

Plant-released flavonoids are detected by rhizobia through a variety of Nod D proteins (Schell, 1993). The Nod D proteins of several species are believed to be membrane associated (Schlaman et al., 1989). Many species of rhizobia have more than one copy of the nodD gene, and the properties of different $\operatorname{nod} D$ genes vary within the same strain as well as from one Rhizobium species to another. Some strains possess two to five copies of nodD (Gottfert et al., 1992; van Rhijn et al., 1993; Fellay et al., 1995; Schlaman et al., 1998), and may in addition possess one or two copies of another LySR-type regulator gene called syrM (symbiotic regulator) (Mulligan and Long, 1989; Michiels et al., 1993, 1995; Swanson et al., 1993; Hanin et al., 1998). SyrM is a Nod D homolog and also acts as an activator of nod genes (Brencic and Winans, 2005).

Chitolipooligosaccharide Nod factors are vital signals for rhizobial entry into legume roots (Relic et al., 1994) and the success or otherwise of the infection process is in large part determined by their structural features. Application of nanomolar or femtomolar concentrations of purified rhizobial Nod factor to the roots of an appropriate legume host elicits responses like deformation of root hairs (Lerouge et al., 1990) accompanied by root hair plasma membrane depolarization (Ehrhardt 
et al., 1996); rapid increases then oscillations in intracellular free calcium in root hairs, referred to as calcium spiking (Ehrhardt et al., 1996; Gehring et al., 1997; Wais et al., 2000, 2002; Walker et al., 2000); change in the root hair cytoskeleton (Cardenas et al., 1998; Timmers et al., 1998); preinfection thread formation in deformed root hairs (van Brussel et al., 1992); and localized cortical cell division at the sites of root nodule primordia (Spaink, 1992; Spaink et al., 1993; LopezLara et al., 1995). Nod factors alone can induce some of the plant genes (nodulins) that are expressed in the preinfection, infection, nodule development, and nodule function phases of symbiotic interaction, some examples of the more rapidly expressed genes being enod12 (Scheres et al., 1990), enod40 (Kouchi and Hata, 1993), ripl (Cook et al., 1995) and $d d 23 b$ (Crockard et al., 2002). Nod factors also control the number of nodules formed on a root system by inducing an autoregulation response in the host plant (van Brussel et al., 2002). A symbiosis receptor-like kinase (SYMRK) gene in Lotus (Stracke et al., 2002) and a nodulation receptor kinase (NORK) in Medicago (Endre et al., 2002) that is required for early signal transduction in both rhizobial and mycorrhizal symbioses have recently been discovered. More recently, two genes that encode LysM receptor-like kinases that function upstream of SYMRK and could be direct receptors for rhizobial Nod factors were discovered in Lotus japonicus (Madsen et al., 2003; Radutoiu et al., 2003).

\subsection{Nod factor (NF) signaling in root epidermis}

Two genes in L. japonicus, LjNFR1 and LjNFR5, have been predicted to function in Nod-factor perception. Both encode receptor-like kinases with LysM domains in the predicted extracellular domain (Madsen et al., 2003; Radutoiu et al., 2003). In $M$. truncatula, two additional receptor-like kinase genes (MtLYK3 and MtLYK4) that encode LysM domains have been identified, and they are thought to be orthologous to PSSYM2A (Limpens et al., 2003); both of these show strong similarity to LjNFR1. The LysM domains are the binding sites for peptidoglycan and binding seems to be the $\mathrm{N}$-acetyl-glucosamine$\mathrm{N}$-acetylmureine backbone (Steen et al., 2003). LysM domain is the peptidoglycan-binding motif found in many bacterial peptidoglycan-binding proteins (Stacey et al., 2006). In addition, LysM domains are present in two proteins that are known to bind chitin (Ponting et al., 1999), which is chemically identical to the Nod factor $\mathrm{N}$-acetylgluscosamine backbone. Furthermore, chitin oligomers can induce $\mathrm{Ca}^{2+}$ spiking in legumes (Walker et al., 2000; Oldroyd et al., 2001). The analogy to Nod-factor binding is striking and the LysMreceptor-like kinases seem excellent candidates for Nod-factor receptors (Oldroyd and Downie, 2004).

Several other components that are essential for most of the early steps in NF signaling have been identified, and these are active directly downstream of the NF receptors. In $M$. truncatula, these genes are named DOESN'T MAKE INFECTIONS1 (DMI1), DMI2 and DMI3, and NODULATION SIGNALING PATHWAY1 (NSP1) and NSP2 (Catoira et al., 2000; Oldroyd and Long, 2003). All of these genes are essential for the NF- induced changes in gene expression showing their importance in NF signaling (Mitra et al., 2004). MtDMII and MtDMI2 are positioned upstream of NF-induced $\mathrm{Ca}^{2+}$ spiking, whereas, $M t D M I 3$ and the MtNSPs are active downstream of $\mathrm{Ca}^{2+}$ spiking (Wais et al., 2000; Oldroyd and Long, 2003). The oscillations of $\mathrm{Ca}^{2+}$ concentration known as $\mathrm{Ca}^{2+}$ spiking occurs in the perinuclear region of epidermal cells and induced within a few minutes of exposure to NFs (Ehrhardt et al., 1996). Pharmacological studies show that $\mathrm{Ca}^{2+}$ spiking is essential for NF-induced gene expression as visualized with the marker gene EARLY NODULIN 11 (ENOD11) (Engstrom et al., 2002; Charron et al., 2004; Geurts et al., 2005).

Rhizobial Nod factors induce in their legume hosts the expression of many genes and set in motion developmental processes leading to root nodule formation. Smit et al. (2005) have reported the identification of the Medicago GRAS-type protein Nodulation Signaling Pathway 1 (NSP1), which is essential for all known Nod factor induced changes in gene expression. Rhizobial Nod factors induce in their legume hosts the expression of many genes and set in motion developmental processes leading to root nodule formation. Smit et al. (2005) have reported the identification of the Medicago GARS-type protein Nodulation signaling pathway 1 (NSP1), which is essential for all known Nod factor-induced changes in gene expression. Kaló et al. (2005) have shown that nodulation signaling pathway genes (NAP2) from Medicago truncatula encodes a GARS protein essential for Nod-factor signaling. NSP2 functions downstream of Nod-factor-induced calcium spiking and a calcium/calmodulin-dependent protein kinase. Their work has provided evidence that a protein transduces calcium signal in plants and provides a possible regulator of Nod- factor-inducible gene expression.

\subsection{Ion fluctuations}

A very early response induced by Nod factors in root hairs is the transient activation of ionic fluxes (Crespi and Galvez, 2000). A number of studies using calcium dyes and ionselective electrodes have indicated considerable Nod factorinduced calcium changes in the root hair cells (Cardenas et al., 2000). Nod factors, when added to legume roots, induce two phases of ionic changes that can be observed in root-hair cells. One is a rapid influx of $\mathrm{Ca}^{2+}\left(\mathrm{Ca}^{2+} \mathrm{flux}\right)$, which is immediately followed by membrane depolarization. Some minutes later, oscillations in the cytosolic $\mathrm{Ca}^{2+}$ concentration (calcium spiking) are induced (Oldroyd and Downie, 2004).

\subsection{Calcium flux and spiking}

Felle et al. $(1998,1999)$ used ion-specific micro-electrodes and observed a rapid Nod-factor-induced $\mathrm{Ca}^{2+}$ influx followed by the efflux of $\mathrm{Cl}^{-}$, then $\mathrm{K}^{+}$and an alkalinization of the cytoplasm (Felle et al., 1996), within one minute of adding Nod factor. Membrane depolarization was induced over a range of Nod-factor concentrations $\left(10^{-10}-10^{-7} \mathrm{M}\right)$ with half maximal induction at $10^{-9} \mathrm{M}$ and no response at $10^{-11} \mathrm{M}$ (Felle et al., 
1998, 1999, 2000). The $\mathrm{Ca}^{2+}$ influx might trigger the activation of an anion channel that allows $\mathrm{Cl}^{-}$efflux and $\mathrm{K}^{+}$might serve as a charge balance, which eventually stops the depolarization and initiates repolarization (Felle et al., 1998). Increased $\mathrm{Ca}^{2+}$ concentrations at the tip of growing root hairs establishes a gradient of $\mathrm{Ca}^{2+}$ down the root hair. Adding Nod factor accentuates this gradient (Cardenas et al., 1999) and induces a wave of $\mathrm{Ca}^{2+}$ that migrates down the shaft of the root-hair cell towards the nucleus (Shaw and Long, 2003). Isolated regions of high $\mathrm{Ca}^{2+}$ concentrations are observed in a diversity of legumes (Pisum sativum, Medicago sativum, Medicago truncatula, Phaseolus vulgaris) (Ehrhardt et al., 1996; Cardenas et al., 1999; Walker et al., 2000; Shaw and Long, 2003). Together, the data can be incorporated into a model in which Nod factors activate a $\mathrm{Ca}^{2+}$ flux at the tip of root hair cells, with at least some of this $\mathrm{Ca}^{2+}$ originating from the external medium (Oldroyd and Downie, 2004).

Oscillations in cytosolic $\mathrm{Ca}^{2+}\left(\mathrm{Ca}^{2+}\right.$ spiking $)$ have been observed in legume root-hair cells following the addition of Nod factor (Ehrhardt et al., 1996; Cardenas et al., 1999; Wais et al., 2000; Walker et al., 2000; Harris et al., 2003). Nodfactor-induced $\mathrm{Ca}^{2+}$ spiking occurs with a lag of approximately 10 minutes following the application of either Nod factor or rhizobia (Wais et al., 2002). The $\mathrm{Ca}^{2+}$ spikes are predominantly restricted to the region of the cytosol that is associated with the nucleus (Ehrhardt et al., 1996; Walker et al., 2000). Individual $\mathrm{Ca}^{2+}$ spikes have a very rapid initial $\mathrm{Ca}^{2+}$ increase, followed by a more gradual decline.

\subsection{Rhizobial induced gene expression in plants for nodule organogenesis}

During the nodule development, many plant genes, the socalled nodulin genes (van Kammen, 1984), need to be coordinately induced in the different steps of the process. Rhizobial induced genes fall into two major classes: the early nodulins $(E N O D)$ and the late nodulins (Nap and Bisseling, 1990). The late nodulins represent genes that are induced many days after the application of bacteria, during a period of nodule maturation. Early nodulins are induced within the first few days of the infection, a period prior to and during the initiation of nodule primordia. ENOD12, ENOD40, RIP1 are all activated within a few hours of application of Nod factor or rhizobia (Scheres et al., 1990; Pichon et al., 1992; Cook et al., 1995; Minami et al., 1996). ENOD12 and RIPl are initially activated in the epidermis of the root in a zone where the root hairs are most responsive to the bacteria (Pichon et al., 1992; Cook et al., 1995). ENOD40 genes code for RNAs (around 700 base pairs) that contain only short ORFs in their sequences (10 37 amino acids) (Crespi et al., 1994). ENOD40 expression, on the other hand, is associated with the nodule primordium and other mitotically active cells throughout the plant, suggesting a role for ENOD4O in a plant meristematic program (Kouchi and Hata, 1993; Yang et al., 1993; Asad et al., 1994; Crespi et al., 1994). The fact that ENOD12 and RIP1 are induced rapidly upon application of low concentrations of Nod factor suggests that these genes are candidates for activation di- rectly from the Nod factor signal transduction pathway. However, ENOD12 and RIP1 have non-symbiotic expression, including root meristematic expression of ENOD12, suggesting additional non-symbiotic regulation (Cook et al., 1995; Bauer et al., 1996). ENOD40, however, is activated by high concentrations of Nod factor that are sufficient to induce cortical cell division (Hirsch et al., 1989; Cooper and Long, 1994; Hirsch and Fang, 1994). Apart from these nodulin genes, other related to nitrogen fixation and assimilation have been detected, such as sucrose synthase, GS, GOGAT, PEPC, carbonic anhydrase, and aspartate aminotransferase (Vance and Gantt, 1992; Shi et al., 1997). These latter genes are mainly expressed in the symbiotic zone and induced late in nodule development except for carbonic anhydrase whose transcripts accumulate specifically in the inner cortical cells (Coba de la Pena et al., 1997), the same cells, involved in oxygen permeability.

\section{INFECTION AND NODULE ORGANOGENESIS}

\subsection{Root hair curling}

The symbiotic interaction starts when the bacteria colonize the root surface and induce curling of the root hair tips (Schultze et al., 1994; Long, 1996). Root hair curling is thought to be caused by a gradual and constant reorientation of the growth direction of the root hair (Emons and Mulder, 2000). The bacteria become entrapped within the pocket of the curl, where the plant cell wall is locally degraded, the cell membrane invaginated and new material deposited by both plant and bacteria (Limpens and Bisseling, 2003). Simultaneously, pericycle and cortical cells are activated for division, usually in front of a xylem pole, close to the infection point. The cortical cells actively divide to form the nodule primordium wherein large amounts of amyloplasts accumulate (Crespi and Galvez, 2000). Root-hair curling only occurs in a few hairs in the root zone that is susceptible to rhizobia, whereas most root hairs within this zone show altered behaviour, resulting in so called root hair deformations (Heidstra et al., 1994). These deformations are the result of isotopic growth, by a reinitiation of tip growth in an altered growth direction (De Ruijter et al., 1998). Although many bacteria can be attached to a single hair, it is probable that one or only a few bacteria induce the curling (Gage and Margolin, 2000; Gage, 2002). The growth direction of the hair needs to be constantly redirected towards the bacteria in order for them to become entrapped.

At the root surface, rhizobia caught in the root hairs, locally degrade the plant cell walls, and infection develops that grows within the root hair. Before the infection thread reaches the base of the root hair cell, the root cortical cells are induced to dedifferentiate, activating their cell - cycle and causing them to divide to form the nodule primordium. In addition to the cortical cells, pericycle cells are also activated and undergo some cell divisions (Stacey et al., 2006). The infection thread, (only 1-5\%) (Crespi and Galvez, 2000), traverses the outer cell layers to reach the nodule primordium. The infection threads penetrate and ramify into primordium cells traversing their walls, 
they then enter cortical cells, initiating a differentiation process that is heralded by cell enlargement (Crespi and Galvez, 2000). Within the infection thread, the rhizobia multiply, but remain confined by the plant cell wall. As the primordia develops into a nodule, bacteria are released from the tip of the infection thread by endocytosis and differentiate into bacteroids surrounded by peribacteroid membrane (Hirsch, 1992).

\subsection{Bacteroid formation}

The release of bacteria into plant cells is initiated by the formation of an infection droplet. Infection droplets can form at the tip of short intracellular infection threads (Cermola et al., 2000) or, more usually at positions in the infection threads where the cell wall gets disrupted and rhizobial cells come into direct contact with the host cell plasma membrane (Brewin, 2004). The plant cell membrane then outgrows and bacteria are taken up into the plant cell lumen by endocytosis. The newly formed structure, which consists of bacteria that are differentiating in bacteroids enclosed in a plant cell membrane, is called a symbiosome. Differentiated bacteroids present an important physiologic adaptation with respect to their enzymatic capacity, notably the production of nitrogenase (Crespi and Galvez, 2000). In determinate nodules, individual symbiosomes fuse and/or bacteroids further divide within the symbiosome, which results in symbiosomes that typically contain several bacteroids. However, in indeterminate nodules, individual symbiosomes further divide, together with the bacteroid, which mostly result in single bacteroids within a symbiosome (Prell and Poole, 2006). The bacterial carbon storage compound polyhydroxybutyrate (PHB) accumulates in rhizobial cells in infection threads (Lodwig et al., 2003, 2005). This suggests that a plentiful carbon supply is available for bacteria during growth in the infection threads.

\subsection{Symbiosome}

The symbiosome is critical for biological nitrogen fixation, (Catalano et al., 2004). While being released from the infection thread into the plant cytoplasm, a plasmalemmaderived symbiosome membrane forms an uninterrupted envelope around each bacterium and delineates the symbiosome space between the symbiosome membrane and the bacterial outer membrane. The symbiosome membrane, bacteroid, and symbiosome space form the basis of the symbiosome (Roth et al., 1988). Specifically, the symbiosome membrane serves both as a physical interface and as a mediator of metabolite exchange between the symbionts, both functions being essential for nodule formation. In mature root nodule cells, the symbiosome membrane represents a mixture of proteins that resemble most closely the protein constituents of the plasma membrane and the tonoplast. Proteins involved in transport, energy, metabolic processes, nodule formation and function, signaling, pathogen response, and protein destination have been identified from the symbiosome membrane. Also, channels and bacterial proteins have been identified for this mem- brane (Udvardi and Day, 1997; Lodwig et al., 2003). The symbiosome membrane must proliferate in enlarged infected root nodule cells to accommodate bacteroid growth and division. During this process of symbiosome membrane proliferation, a large amount of lipid and protein synthesis is required since infected root nodule cells typically consist of hundreds of bacteroids, each enclosed by their own symbiosome membrane. Symbiosome membrane biogenesis and demand in infected plant cells is 30 times greater than that required for plasma membrane synthesis (Catalano et al., 2004).

\section{CONCLUSIONS AND FUTURE PROSPECTS}

Legumes form novel plant organs, the "root nodules", in response to lipooligosaccharide signals, "Nod factors", delivered by specific soil bacteria called rhizobia. The adoption of model legumes for genetic analysis of nodulation has led to major advances in our understanding of initial steps in Nod signal recognition and subsequent signaling, however, a complete picture of the genetic interplay involved in rhizobial symbiosis is yet to appear. There are still a number of genes, with a role in Nod-factor signal transduction that remain to be cloned. Detangling of this system (legume-Rhizobium symbiosis) would help in better understanding of the molecular mechanisms governing nodule differentiation. With a complete understanding of early signaling pathways, quest like which genes are responsible for nodule formation and which genes are missing from crop plants such as wheat and rice that do not form endosymbiosis with nitrogen-fixing bacteria will be answered.

Acknowledgements: The financial support provided by Council of Scientific and Industrial Research, New Delhi, India is thankfully acknowledged.

\section{REFERENCES}

Asad S., Fang Y., Wyco K.L., Hirsch A.M. (1994) Isolation and characterisation of cDNA and genomic clones of MSENOD40; transcripts are detected in meristematic cells of alfalfa, Protoplasma 183, 1023 .

Barbour W.M., Hattermann D.R., Stacey G. (1991) Chemotaxis of Bradyrhizobium japonicum to soybean exudates, Appl. Environ. Microb. 57, 2635-2639.

Bauer P., Ratet P., Crespi M.D., Schultze M., Kondorosi A. (1996) Nod factors and cytokinins induce similar cortical cell division, amyloplast deposition and MsENOD12A expression patterns in alfalfa roots, Plant J. 10, 91-105.

Bergman K., Nulty E., Su L.H. (1991) Mutations in the 2 flagellin genes of Rhizobium meliloti, J. Bacteriol. 173, 3716-3723.

Bladergroen M., Spaink H.P. (1998) Genes and signal molecules involved in the rhizobia Leguminoseae symbiosis, Curr. Opin. Plant Biol. 1, 353-359.

Bohlool B.B., Ladha J.K., Garrity D.P., George T. (1992) Biological nitrogen fixation for sustainable agriculture: A perspective, Plant Soil $141,1-11$.

Bonfante P. (2003) Plants, mycorrhizal fungi and endobacteria: a dialogue among cells and genomes, Biol. Bull-US 204, 215-220. 
Bourdineaud J.P., Bono J.J., Ranjeva R., Cullimore J.V. (1995) Enzymatic radiolabelling to a high specific activity of legume lipo-oligosaccharidic nodulation factors from Rhizobium meliloti, Biochem. J. 306, 259-264.

Brencic A., Winans S.C. (2005) Detection of and response to signals involved in host-microbe interactions by plant-associated bacteria, Microbiol. Mol. Biol. R. 69, 155-194.

Brewin N.J. (2004) Plant cell wall remodelling in the rhizobium-legume symbiosis, Crit. Rev. Plant Sci. 23, 293-316.

Broughton W.J., Jabbouri S., Perret X. (2000) Keys to symbiotic harmony, J. Bacteriol. 182, 5641-5652.

Cárdenas L., Feijó J.A., Kunkel J.G., Sánchez F., Holdaway-Clarke T., Hepler P.K., Quinto C. (1999) Rhizobium Nod factors induce increases in intracellular free calcium and extracellular calcium influxes in bean root hairs, Plant J. 19, 347-52.

Cardenas L., Holdawa-Clarke T.L., Sanchez F., Quinto C., Feijo J.A., Kunkel J.G., Hepler P.K. (2000) Ion changes in legume root hairs responding to Nod factors, Plant Physiol. 123, 443-451.

Cárdenas L., Vidali L., Domínguez J., Pérez H., Sánchez F., Hepler P.K., Quinto C. (1998) Rearrangement of actin microfilaments in plant root hairs responding to Rhizobium etli nodulation signals, Plant Physiol. 116, 871-877.

Catalano C.M., Lane W.S., Sherrier D.J. (2004) Biochemical characterization of symbiosome membrane proteins from Medicago truncatula root nodules, Electrophoresis 25, 519-531.

Catoira R., Galera C., De Billy F., Penmetsa R.V., Journet E.P., Maillet F. Rosenberg C., Cook D., Gough C., Dénarié J. (2000) Four genes of Medicago truncatula controlling components of a Nod factor transduction pathway, Plant Cell 12, 1647-1666.

Cermola M., Fedorova E., Taté R., Riccio A., Favre R., Patriarca E.J. (2000) Nodule invasion and symbiosome differentiation during Rhizobium etli Phaseolus vulgaris symbiosis, Mol. Plant Microbe Int. 13, 733-741.

Charron D., Pingret J.L., Chabaud M., Journet E.P., Barker D.G. (2004) Pharmacological evidence that multiple phospholipid signaling pathways link Rhizobium nodulation factor perception in Medicago truncatula root hairs to intracellular responses, including $\mathrm{Ca}^{2+}$ spiking and specific ENOD gene expression, Plant Physiol. 136, 35823593.

Chen T.H.H., Murata N. (2002) Enhancement of tolerance of abiotic stress by metabolic engineering of betaines and other compatible solutes, Curr. Opin. Plant Biol. 5, 250-257.

Coba de la Pena T., Frugier F., McKhann H.I., Bauer P., Brown S. Kondorosi A., Crespi M. (1997) A carbonic anhydrase gene is induced in the nodule primordium and its cell-specific expression is controlled by the presence of Rhizobium during development, Plant J. $11,407-420$.

Cook D.R., Dreyer D., Bonnet D., Howell M., Nony E., Vandenbosch K. (1995) Transient induction of a peroxidase gene in Medicago truncatula precedes infection by Rhizobium meliloti, Plant Cell 7 , $43-55$.

Cooper J. (2004) Multiple responses of rhizobia to flavonoids during legume root infection, in: Callow J.A. (Ed.), Advances in botanical research: Incorporating advances in plant pathology, Academic Press, pp. 1-62.

Cooper J., Long S.R. (1994) Morphogenetic rescue of Rhizobium meliloti nodulation mutants by trans-zeatin secretion, Plant Cell 6, 215-225.

Crespi M., Galvez S. (2000) Molecular mechanisms in root nodule development, J. Plant Growth Regul. 19, 155-166.

Crespi M.D., Jurkevitch E., Poiret M., D’Aubenton-Carafa Y., Petrovics G., Kondorosi E., Kondorosi A. (1994) Enod40, a gene expressed during nodule organogenesis, codes for a nontranslatable RNA involved in plant growth, EMBO J. 13, 5099-5112.

Crockard M., Bjourson A., Dazzo F., Cooper J. (2002) A white clover nodulin gene, $d d 23 b$, encoding a cysteine cluster protein, is expressed in roots during the very early stages of interaction with Rhizobium leguminosarum biovar trifolii and after treatment with chitolipooligosaccharide Nod factors, J. Plant Res. 115, 439-447.

Cullimore J.V., Ranjeva R., Bono J.J. (2001) Perception of lipochitooligosaccharidic Nod factors in legumes, Trends Plant Sci. 6, 24-30.

Cunningham S., Kollmeyer W.D., Stacey G. (1991) Chemical control of interstrain competition for soybean nodulation by Bradyrhizobium japonicum, Appl. Environ. Microb. 57, 1886-1892.

De Ruijter N.C.A., Rook M.B., Bisseling T., Emons A.M.C. (1998) Lipochito-oligosaccharides re-initiate root hair tip growth in Vicia sativa with high calcium and spectrin-like antigen at the tip, Plant J. $13,341-350$.

De'narie J., Debelle F., Truchet G., Prome J.C. (1993) Rhizobium and legume nodulation: A molecular dialogue, in: Palacios R., Moira J., Newton W.E. (Eds.), New Horizons in Nitrogen Fixation, Kluwer, Dordrecht, the Netherlands, pp. 19-30.

Denarie J., Debelle F., Prome J.C. (1996) Rhizobium lipochitooligosaccharide nodulation factors: signalling molecules mediating recognition and morphogenesis, Annu. Rev. Biochem. $65,503-535$.

Downie J.A. (1998) Functions of rhizobial nodulation genes, in: Spaink H.P., Kondorosi A., Hooykaas P.J.J. (Eds.), The Rhizobiaceae, Kluwer Academic Publishers, Dordrecht, The Netherlands, pp. 387-402.

Downie J.A., Walker S.A. (1999) Plant responses to nodulation factors, Curr. Opin. Plant Biol. 2, 483-489.

Doyle J.J. (2001) Leguminosae, in: Brenner S., Miller J.H. (Eds.), Encyclopedia of Genetics, Academic Press, San Diego, pp. 10811085.

Ehrhardt D.W., Atkinson E.M., Faull K.F., Freedberg D.I., Sutherlin D.P., Armstrong R., Long S.R. (1995) In Vitro sulfotransferase activity of NodH, a nodulation protein of Rhizobium meliloti required for host-specific nodulation, J. Bacteriol. 177, 6237-6245.

Ehrhardt D.W., Wais R., Long S.R. (1996) Calcium spiking in plant root hairs responding to Rhizobium nodulation signals, Cell 85, 673681 .

Emons A.M.C., Mulder B. (2000) Nodulation factors trigger an increase of fine bundles of subapical actin filaments in Vicia root hairs: implication for root hair curling around bacteria, in: De Wit P.J.G.M., Bisseling T., Stiekema J.W. (Eds.), Biology of Plant-Microbe Interactions, St. Paul, Minnesota: The International Society of Molecular Plant-Microbe Interaction, Vol. 2, pp. 272-276.

Endre G., Kereszt A., Kevei Z., Mihacea S., Kalo P., Kiss G.B. (2002) A receptor kinase gene regulating symbiotic nodule development, Nature 417, 962-966.

Engstrom E.M., Ehrhardt D.W., Mitra R.M., Long S.R. (2002) Pharmacological analysis of nod factor-induced calcium spiking in Medicago truncatula. Evidence for the requirement of type IIA calcium pumps and phosphoinositide signaling, Plant Physiol. 128, 1390-1401

Farrand S.K., Van Berkum P.B., Oger P. (2003) Agrobacterium is a definable genus of the family Rhizobiaceae, Int. J. Syst. Evol. Microbiol. $53,1681-1687$

Fellay R., Perret X., Viprey V., Broughton W.J., Brenner S. (1995) Organization of host-inducible transcripts on the symbiotic plasmid of Rhizobium sp. NGR234, Mol. Microbiol. 16, 657-667. 
Felle H.H., Kondorosi E., Kondorosi A., Schultze M. (1996) Rapid alkalinization in alfalfa root hairs in response to rhizobial lipochitooligosaccharide signals, Plant J. 10, 295-301.

Felle H.H., Kondorosi E., Kondorosi A., Schultze M. (1998) The role of ion fluxes in Nod factor signalling in Medicago sativa, Plant J. 13, 455-463.

Felle H.H., Kondorosi E., Kondorosi A., Schultze M. (1999) Elevation of the cytosolic free $\mathrm{Ca}^{2+}$ is indispensable for the transduction of the Nod factor signal in alfalfa, Plant Physiol. 121, 273-279.

Felle H.H., Kondorosi E., Kondorosi A., Schultze M. (2000) How alfalfa root hairs discriminate between Nod factors and oligochitin elicitors, Plant Physiol. 124, 1373-1380.

Gage D.J. (2002) Analysis of infection thread development using GFPand dsRED-expressing Sinorhizobium meliloti, J. Bacteriol. 184, 7042-7046.

Gage D.J., Margolin W. (2000) Hanging by a thread: invasion of legume plants by rhizobia, Curr. Opin. Microbiol. 3, 613-617.

Gagnon H., Ibrahim R.K. (1998) Aldonic acids: a novel family of nod gene inducers of Mesorhizobium loti, Rhizobium lupini, and Sinorhizobium meliloti, Mol. Plant Microbe Int. 11, 988-998.

Gehring C.A., Irving H.R., Kabbara A.A., Parish R.W., Boukli N.M. Broughton W.J. (1997) Rapid, plateau-like increases in intracellular free calcium are associated with nod-factor-induced root-hair deformation, Mol. Plant Microbe Int. 10, 791-802.

Geremia R.A., Mergaert P., Geelen D., Van Montagu M., Holsters M. (1994) The NodC protein of Azorhizobium caulinodans is an $N$ acetylgucosamin-yltransferase, Proc. Natl Acad. Sci. (USA) 91, 2669-2673.

Geurts R., Bisseling T. (2002) Rhizobium Nod factor perception and signalling, Plant Cell 14, S239-S249.

Geurts R., Fedorova E., Bisseling T. (2005) Nod factor signaling genes and their function in the early stages of Rhizobium infection, Curr. Opin. Plant Biol. 8, 346-352.

Gottfert M., Holzhauser D., Bani D., Hennecke H. (1992) Structural and functional analysis of 2 different nodD genes in Bradyrhizobium japonicum USDA110, Mol. Plant Microbe Int. 5, 257-265.

Graham T.L. (1991) Flavonoid and isoflavonoid distribution in developing soybean seedling tissues and in seed and root exudates, Plant Physiol. 95, 594-603.

Hadri A., Bisseling T. (1998) Responses of the plant to Nod factors, The Rhizobiaceae, in: Spaink H.P., Kondorosi A., Hooykaas P.J.J. (Eds.), Kluwer Academic Publishers, Dordrecht, The Netherlands, pp. $403-416$.

Hanin M., Jabbouri S., Broughton W.J., Fellay R. (1998) SyrM1 of Rhizobium sp. NGR234 activates transcription of symbiotic loci and controls the level of sulfated Nod factors, Mol. Plant Microbe Int. $11,343-350$.

Harborne J.B., Williams C.A. (2001) Anthocyanins and other flavonoids, Nat. Prod. Rep. 18, 310-333.

Harborne J.B., Williams C.A. (2000) Advances in flavonoid research since 1992, Phytochemistry 55, 481-504.

Harris J.M., Wais R., Long S.R. (2003) Rhizobium-induced calcium spiking in Lotus japonicus, Mol. Plant Microbe Int. 16, 335-341.

Hartwig U.A., Maxwell C.A., Joseph C.M., Phillips D.A. (1990) Effects of alfalfa nod gene-inducing flavonoids on nodABC transcription in Rhizobium meliloti strains containing different nodD genes, J. Bacteriol. 172, 2769-2773.

Hartwig U.A., Phillips D.A. (1991) Release and modification of nod gene-inducing flavonoids from alfalfa seeds, Plant Physiol. 95, 804-807.
Heeb S., Haas D. (2001) Regulatory roles of the GacS/GacA twocomponent system in plant-associated and other gram-negative bacteria, Mol. Plant Microbe Int. 14, 1351-1363.

Heidstra R., Geurts R., Franssen H., Spaink H.P., Van Kammen A., Bisseling T. (1994) Root hair deformation activity of nodulation factors and their fate on Vicia sativa, Plant Physiol. 105, 787-797.

Hirsch A.M. (1992) Developmental biology of legume nodulation, New Phytol. 122, 211-237.

Hirsch A.M., Bhuvaneswari T.V., Torrey J.G., Bisseling T. (1989) Early nodulin genes are induced in alfalfa root outgrowths elicited by auxin transport inhibitors, Proc. Natl Acad. Sci. (USA) 86, 12441248 .

Hirsch A.M., Fang Y. (1994) Plant hormones and nodulation: what's the connection, Plant Mol. Biol. 26, 5-9.

Hirsch A.M., Lum M.R., Downie J.A. (2001) What makes the rhizobialegume symbiosis so special? Plant Physiol. 127, 1484-1492.

Hirsch A.M. (2004) Plant-microbe symbioses: A continuum from commensalism to parasitism, Symbiosis 37, 345-363.

Horvath B., Heidstra R., Lados M., Moerman M., Spaink H.P., Prome J.C., Vankammen A., Bisseling T. (1993) Lipo-oligosaccharides of Rhizobium induce infection-related early nodulin gene-expression in pea root hairs, Plant J. 4, 727-733.

Ielpi L., Dylan T., Ditta G.S., Helinski D.R., Stanfield S.W. (1990) The $n d v B$ locus of Rhizobium meliloti encodes a $319-\mathrm{kDa}$ protein involved in the production of beta- (1-2)-glucan, J. Biol. Chem. 265, $2843-2851$

John M., Rohrig H., Schmidt J., Wieneke U., Schell J. (1993) Rhizobium NodB protein involved in nodulation signal synthesis is a chitooligosaccharide deacetylase, Proc. Natl Acad. Sci. (USA) 90, 625-629.

Kaló P., Gleason C., Edwards A., Marsh J., Mitra R.M., Hirsch S., Jakab J., Sims S., Long S.R., Rogers J., Kiss G.B., Downie J.A., Oldroyd G.E.D. (2005) Nodulation signaling in legumes requires NSP2, a member of the GRAS family of transcriptional regulators, Science $308,1786-1789$

Kape R., Parniske M., Werner D. (1991) Chemotaxis and nod gene activity of Bradyrhizobium japonicum in response to hydroxycinnamic acids and isoflavonoids, Appl. Environ. Microbiol. 57, 316-319.

Kinzig A.P., Socolow R.H. (1994) Human impacts on the nitrogen cycle, Phys. Today 47, 24-31.

Kouchi H., Hata S. (1993) Isolation and characterization of novel nodulin cDNAs representing genes expressed at early stages of soybean nodule development, Mol. Gen. Genet. 238, 106-119.

Lerouge P., Roche P., Faucher C., Maillet F., Truchet G., Promé J.C., Dénarié J. (1990) Symbiotic host-specificity of Rhizobium meliloti is determined by a sulphated and acylated glucosamine oligosaccharide signal, Nature 344, 781-784.

Limpens E., Bisseling T. (2003) Signaling in symbiosis, Curr. Opin. Plant Biol. 6, 343-350.

Limpens E., Franken C., Smit P., Willemse J., Bisseling T., Geurts R. (2003) LysM domain receptor kinases regulating rhizobial nod factor-induced infection, Science 24, 630-633.

Lodwig E.M., Hosie A.H.F., Bourdès A., Findlay K., Allaway D., Karunakaran R., Downie J.A., Poole P.S. (2003) Amino-acid cycling drives nitrogen fixation in the legume-Rhizobium symbiosis, Nature 422, 722-726.

Lodwig E.M., Leonard M., Marroqui S., Wheeler T.R., Findlay K., Downie J.A., Poole P.S. (2005) Role of polyhydroxybutyrate and glycogen as carbon storage compounds in pea and bean bacteroids, Mol. Plant Microbe Int. 18, 67-74. 
Long S.R. (1996) Rhizobium symbiosis: Nod factors in perspective, Plant Cell 8, 1885-1898.

Lopez-Lara I.M., van den Berg J.D.J., Thomas-dates J.E., Glushka J., Lugtenberg B.J.J., Spaink H.P. (1995) Structural identification of the lipo-chitin oligosaccharide nodulation signals of Rhizobium loti, Mol. Microbiol. 15, 627-638.

Madsen E.B., Madsen L.H., Radutoiu S., Olbryt M., Rakwalska M., Szczyglowski K., Sato S., Kaneko T., Tabata S., Sandal N., Stougaard J. (2003) A receptor kinase gene of the LysM type is involved in legumeperception of rhizobial signals, Nature 425, 637640.

Michiels J., De Wilde P., Vanderleyden J. (1993) Sequence of the Rhizobium leguminosarum biovar phaseoli syrM gene, Nucleic Acids Res. 21, 3893.

Michiels J., Pelemans H., Vlassak K., Verreth C., Vanderleyden J. (1995) Identification and characterization of a Rhizobium leguminosarum bv. phaseoli gene that is important for nodulation competitiveness and shows structural homology to a Rhizobium fredii host-inducible gene, Mol. Plant Microbe Int. 8, 468-472.

Minami E., Kouchi H., Cohn J.R., Ogawa T., Stacey G. (1996) Expression of the early nodulin, ENOD40, in soybean roots in response to various lipo-chitin signal molecules, Plant J. 10, 23-32.

Mitra R.M., Shaw S.L., Long S.R. (2004) Six non-nodulating plant mutants defective for Nod factor-induced transcriptional changes associated with the legume-rhizobia symbiosis, Proc. Natl Acad. Sci. (USA) 101, 10217-10222.

Mulligan J.T., Long S.R. (1989) A family of activator genes regulates expression of Rhizobium meliloti nodulation genes, Genetics 122, $7-18$.

Nap J.P., Bisseling T. (1990) Developmental biology of a plantprokaryotic symbiosis: the legume root nodule, Science 250,948 954

Oldroyd G.E.D., Long S.R. (2003) Identification and characterization of nodulation-signaling pathway 2 , a gene of Medicago truncatula involved in Nod actor signaling, Plant Physiol. 131, 1027-1032.

Oldroyd G.E.D., Downie J.A. (2004) Calcium, kinases and nodulation signalling in legumes, Nat. Rev. Mol. Cell Biol. 5, 566-576.

Oldroyd G.E.D., Mitra R.M., Wais R.J., Long S.R. (2001) Evidence for structurally specific negative feedback in the Nod factor signal transduction pathway, Plant J. 28, 191-199.

Parniske M., Downie J.A. (2003) Plant biology: locks, keys and symbioses, Nature 425, 569-570.

Peoples M.B., Herridge D.F., Ladha J.K. (1995) Biological nitrogen fixation: An efficient source of nitrogen for sustainable agricultura production? Plant Soil 174, 3-28.

Peoples M.B., Crasswell E.T. (1992) Biological nitrogen fixation: Investments, expectations and actual contributions to agriculture, Plant Soil 141, 13-39.

Perret X., Staehelin C., Broughton W.J. (2000) Molecular basis of symbiotic promiscuity, Microbiol. Mol. Biol. R. 64, 180-201.

Phillips D.A., Dakora F.D., Sande E.S., Joseph C.M., Zon J. (1994) Synthesis, release, and transmission of alfalfa signals to rhizobial symbionts, Plant Soil 161, 69-80.

Phillips D.A., Joseph C.M., Maxwell C.A. (1992) Trigonelline and stachydrine released from alfalfa seeds activate NodD2 protein in Rhizobium meliloti, Plant Physiol. 99, 1526-1531.

Pichon M., Journet E.-P., Dedieu A., de Billy F., Truchet G., Barker D.G. (1992) Rhizobium meliloti elicits transient expression of the early nodulin gene ENOD12 in the differentiating root epidermis of transgenic alfalfa, Plant Cell 4, 1199-1211.
Ponting C.P., Aravind L., Schultz J., Bork P., Koonin E.V. (1999) Eukaryotic signalling domain homologues in archaea and bacteria. Ancient ancestry and horizontal gene transfer, J. Mol. Biol. 289 729-745.

Prell J., Poole P. (2006) Metabolic changes of rhizobia in legume nodules, Trends Microbiol. 14, 161-168.

Radutoiu S., Madsen L.H., Madsen E.M., Felle H.H., Umehara Y., Grønlund M., Sato S., Nakamura Y., Tabata S., Sandal N., Stougaard J. (2003) Plant recognition of symbiotic bacteria requires two LysM receptor-like kinases, Nature 425, 585-592.

Relic B., Perret X., Estrada-Garcia M.T., Kopcinska J., Golinowski W., Krishnan H.B., Pueppke S.G., Broughton W.J. (1994) Nod factors of Rhizobium are a key to the legume door, Mol. Microbiol. 13, 171-178.

Ridge R.W., Kim R., Yoshida F. (1998) The diversity of lectin-detectable sugar residues on root hair tips of selected legumes correlates with the diversity of their host ranges for rhizobia, Protoplasma 202, 8490.

Robertson J.L., Holliday T., Matthysse A.G. (1988) Mapping of Agrobacterium tumefaciens chromosomal genes affecting cellulose synthesis and bacterial attachment to host cells, J. Bacteriol. 170, $1408-1411$.

Robinson J.B., Bauer W.D. (1993) Relationships between C-4 dicarboxylic acid transport and chemotaxis in Rhizobium meliloti, J. Bacteriol. 175, 2284-2291.

Roche P., Debelle F., Maillet F., Maillet L., Faucher C., Truchet G. Denarie J., Prome J.C. (1991) Molecular basis of symbiotic host specificity in Rhizobium meliloti: nodH and nodPO genes encode the sulfation of lipo-oligosaccharide signals, Cell 67, 1131-1143.

Rohrig H., Schmidt J., Wieneke U., Kondorosi E., Barlier I., Schell J., John M. (1994) Biosynthesis of lipooligosaccharide nodulation factors: Rhizobium NodA protein is involved in $\mathrm{N}$-acylation of the chitooligosaccharide backbone, Proc. Natl Acad. Sci. (USA) 91, 3122 3126.

Roth E., Jeon K., Stacey G. (1988) in: Palacios R., Verma D.P.S. (Eds.), Molecular Genetics of Plant-Microbe Interactions, American Phytopathology Society, St Paul, MN, pp. 220-225.

Rozan P., Kuo Y.H., Lambein F. (2000) Free amino acids present in commercially available seedlings sold for human consumption. A potential hazard for consumers, J. Agr. Food Chem. 48, 716-723.

Rozan P., Kuo Y.H., Lambein F. (2001) Amino acids in seeds and seedlings of the genus Lens, Phytochemistry 58, 281-289.

Rudiger H., Gabius H.J. (2001) Plant lectins: occurrence, biochemistry, functions and applications, Glycoconjugate J. 18, 589-613.

Sawada H., Kuykendall L.D., Young J.M. (2003) Changing concepts in the systematics of bacterial nitrogen-fixing legume symbionts, J. Gen. Appl. Microbiol. 49, 155-179.

Schell M.A. (1993) Molecular biology of the LysR family of transcriptional regulators, Annu. Rev. Microbiol. 47, 597-626.

Scheres B., Wiel C.V.D., Zalensky A., Horvath B., Spaink H., van Eck H., Zwartkruis F., Wolters A., Gloudemans T., van Kammen A., Bisseling T. (1990) The ENOD12 gene product is involved in the infection process during the pea-Rhizobium interaction, Cell 60, 281294.

Schlaman H.R., Phillips D.A., Kondorosi E. (1998) Genetic organization and transcriptional regulation of rhizobial nodulation genes, in: Spaink H.P., Kondorosi A., Hooykaas P.J.J. (Eds.), The Rhizobiaceae. Kluwer Academic Publishers, Dordrecht, The Netherlands, pp. 361-386.

Schlaman H.R., Spaink H.P., Okker R.J., Lugtenberg B.J. (1989) Subcellular localization of the nodD gene product in Rhizobium leguminosarum, J. Bacteriol. 171, 4686-4693. 
Schultze M., Kondorosi A. (1998) Regulation of symbiotic root nodule development, Annu. Rev. Genet. 32, 33-57.

Schultze M., Kondorosi É., Ratet P., Buiré M., Kondorosi A. (1994) Cell and molecular biology of Rhizobium-plant interactions, Int. Rev. Cytol. 156, 1-75.

Shaw S.L., Long S.R. (2003) Nod factor elicits two separable calcium responses in Medicago truncatula root hair cells, Plant Physiol. 131, 976-984.

Shi L., Twary S.N., Yoshioka H., Gregerson R.G., Miller S.S., Samac D.A., Gantt J.S., Unfeker P.J., Vance C.P. (1997) Nitrogen assimilation in alfalfa: isolation and characterization of an asparagines synthetase gene showing enhanced expression in root nodules and dark-adapted leaves, Plant Cell 9, 1339-1356.

Smit P., Raedts J., Portyanko V., Debellé F., Gough C., Bisseling T., Geurts R. (2005) NSP1 of the GRAS protein family is essential for rhizobial nod factor-induced transcription, Science 308, 17891791.

Spaink H.P. (1992) Rhizobial lipo-oligosaccharides: answers and questions, Plant Mol. Biol. 20, 977-986.

Spaink H.P. (1996) Regulation of plant morphogenesis by lipo-chitin oligosaccharides, Crit. Rev. Plant Sci. 15, 559-582.

Spaink H.P. (2000) Root nodulation and infection factors produced by rhizobial bacteria, Annu. Rev. Microbiol. 54, 257-288.

Spaink H.P., Wijfjes A.H.M., van V.T.B., Kijne J.W., Lugtenberg B.J.J. (1993) Rhizobial lipo-oligosaccharide signals and their role in plant morphogenesis; are analogous lipophilic chitin derivatives produced by the plant? Aust. J. Plant Physiol. 20, 381-392.

Stacey G., Libault M., Brechenmacher L., Wan J., May G.D. (2006) Genetics and functional genomics of legume nodulation, Curr. Opin. Plant Biol. 9, 110-121.

Stanfield S.W., Ielpi L., O’Brochta D., Helinski D.R., Ditta G.S. (1988) The $n d v A$ gene product of Rhizobium meliloti is required for beta(1-2)glucan production and has homology to the ATP-binding export protein HlyB, J. Bacteriol. 170, 3523-3530.

Steen A., Buist G., Leenhouts K.J., El Khattabi M., Grijpstra F., Zomer A.L., Venema G., Kuipers O.P., Kok J. (2003) Cell wall attachment of a widely distributed peptidoglycan binding domain is hindered by cell wall constituents, J. Biol. Chem. 278, 23874-23881.

Stracke S., Kistner C., Yoshida S., Mulder L., Sato S., Kaneko T., Tabata S., Sandal N., Stougaard J., Szczyglowski K., Parniske M. (2002) A plant receptor-like kinase required for both bacterial and fungal symbiosis, Nature 417, 959-962.

Swanson J.A., Mulligan J.T., Long S.R. (1993) Regulation of syrM and nodD3 in Rhizobium meliloti, Genetics 134, 435-444.

Timmers A.C.J., Auriac M.C., de Billy F., Truchet G. (1998) Nod factor internalization and microtubular cytoskeleton changes occur concomitantly during nodule differentiation in alfalfa, Development $125,339-349$.
Truchet G., Roche P., Lerouge P., Vasse J., Camut S., Debilly F., Prome J.C., Denarie J. (1991) Sulfated lipo-oligosaccharide signals of Rhizobium meliloti elicit root nodule organogenesis in alfalfa, Nature 351, 670-673.

Udvardi M.K., Day D.A. (1997) Metabolite transport across symbiotic membranes of legume nodules, Annu. Rev. Plant Phys. 48, 493523

van Brussel A.A.N., Bakhuizen R., Van Spronsen P.C., Spaink H.P., Tak T., Lugtenberg B.J.J., Kijne J.W. (1992) Induction of preinfection thread structures in the leguminous host plant by mitogenic lipooligosaccharides of Rhizobium, Science 257, 70-72.

van Brussel A.A.N., Tak T., Boot T., Kijne J.W. (2002) Autoregulation of root nodule formation: signals of both symbiotic partners studied in a split-root system of Vicia sativa subsp. nigra, Mol. Plant Microbe Int. $15,341-349$.

van Kammen A. (1984) Suggested nomenclature for plant genes involved in nodulation and symbiosis, Plant Mol. Biol. Rep. 2, 43-45.

van Rhijn P., Feys B., Verreth C., Vanderleyden J. (1993) Multiple copies of nodD in Rhizobium tropici CIAT899 and BR816, J. Bacteriol. $175,438-447$.

Vance C.P., Gantt J.S. (1992) Control of nitrogen and carbon metabolism in root nodules, Physiol. Plantarum 85, 266-274.

Wais R.J., Galera C., Oldroyd G., Catoira R., Penmetsa R.V., Cook D., Gough C., Denarie J., Long S.R. (2000) Genetic analysis of calcium spiking responses in nodulation mutants of Medicago truncatula, Proc. Natl Acad. Sci. (USA) 97, 13407-13412.

Wais R.J., Keating D.H., Long S.R. (2002) Structure-function analysis of nod factor-induced root hair calcium spiking in Rhizobium-legume symbiosis, Plant Physiol. 129, 211-224.

Walker S.A., Viprey V., Downie J.A. (2000) Dissection of nodulation signaling using pea mutants defective for calcium spiking induced by Nod factors and chitin oligomers, Proc. Natl Acad. Sci. (USA) 97, 13413-13418.

Willems A., Collins M.D. (1993) Phylogenetic analysis of rhizobia and agrobacteria based on 16S rRNA gene sequences, Int. J. Syst. Bacteriol. 43, 305-313.

Yang W.C., Katinakis P., Hendriks P., Smolders A., de Vries F., Spree J., van Kammen A., Bisseling T., Franssen H. (1993) Characterization of GmENOD40, a gene showing novel patterns of cell-specific expression during soybean nodule development, Plant J. 3, 573-585.

Zuanazzi J., Clergeot P.H., Quirion J.C., Husson H.P., Kondorosi A., Ratet P. (1998) Production of Sinorhizobium meliloti nod gene activator and repressor flavonoids from Medicago sativa roots, Mol. Plant Microbe Int. 11, 784-794. 